\title{
EFFECTS OF UV RADIATION ON HELICAL TWISTING IN CHOLESTERIC SYSTEMS CONTAINING PHOTOSENSITIVE AZOXY NEMATICS
}

\author{
M.I. SERBINA, N.A. KASIAN, L.N. LISETSKI \\ Institute for Scintillation Materials, STC "Institute for Single Crystals", \\ Nat. Acad. of Sci of Ukraine \\ (60, Lenin Ave., 61001 Kharkiv, Ukraine; e-mail: lisetski@isma. kharkov.ua)
}

PACS 42.70.Df; 61.30.Cz

For cholesteric liquid crystal systems containing photosensitive nematic ZhK-440 and a mixture of cholesterol derivatives, the changes in helical twisting induced by UV radiation are studied. The UV-induced shift of the selective reflection maximum $\lambda_{\max }$ is shown to depend on the concentration of the nematic component. For low concentrations of ZhK-440, $\lambda_{\max }$ increases, which correlates with the corresponding temperature-induced changes. For higher azoxy nematic concentrations, $\lambda_{\max }$ decreases, regardless of the temperature behavior of the system. To explain the experimental data, a theoretical description is proposed on the basis of the development of molecular models of helical twisting. Good agreement was obtained between calculated and measured values of the UV-induced shift as a function of the azoxy nematic concentration, with two extrema and an inversion point. The extra twisting arises from the cholesteric mesophase-induced orientation of short molecular axes of cis-isomers formed as a result of irradiation.

\section{Introduction}

Tunable dye lasers based on cholesteric liquid crystals, first reported in [1], have attracted a renewed interest from the standpoint of both liquid crystal physics and laser optics $[2,3]$. Since the lasing wavelength of such "distributed feedback" lasers essentially depends on the location of a selective reflection band of the cholesteric matrix, a convenient way of tuning can be based on changing the helical pitch (i.e., selective reflection maximum) by UV irradiation [4-8].

The phototuning effect is based on the presence of a photosensitive conformationally active component in the cholesteric system. Among the most promising are azoand azoxy compounds, which are characterized by the trans-cis isomerization under UV irradiation. Especially promising is the use of azo- or azoxybenzene-based nematics. Under normal conditions, these substances are in the trans-state; under UV irradiation within the absorption band ( $\sim 300-370 \mathrm{~nm})$, a cis-isomer is formed in concentrations up to $\sim 50 \%$ and more [9]. The reverse transition (cis-trans) occurs under irradiation at longer wavelengths ( 400-450 nm) or spontaneously after several days of dark storage. An accompanying effect of UV irradiation is a strong suppression of the nematicisotropic transition temperature, which is evidently due to a very small anisometry of the emergent cis-form.

The literature data on a variation of the helical twisting in such systems are contradictory. Both increase and decrease of the helical pitch $p$ (and, correspondingly, of the maximum selective reflection wavelength $\lambda_{\max }=n p$ ) were reported. As a rule, no data on the helical pitch temperature dependence were given, and shifts of $\lambda_{\max }$ were reported only for room temperature. However, it was noted in $[10,11]$ that the typical behavior in most systems was the decreasing helical pitch (i.e., an enhancement of the helical twisting), regardless of a positive $(d p / d T>0)$ or negative $(d p / d T<0)$ variation of the helical pitch with temperature.

It could be expected from general considerations that the accumulation of the cis-isomer should lead to consequences similar to those caused by introduction of a nonmesogenic dopant, i.e., the worsening of the orientational order and an increase in the effective temperature of the system $[12,13]$. Thus, the effects of temperature and UV irradiation on the helical pitch in each specific system should be similar. It should be noted that an anomalous decrease in the helical pitch was observed both for steroid cholesterics (based on cholesterol esters) and for induced cholesterics (chiral nematics). This does not allow explaining this effect as a result of the "extra helical twisting" characteristic for nematic-cholesteric mixtures [12]. Moreover, it was shown that photoinduced changes in the helical pitch could be several times higher than temperature changes over all the temperature range [14]. The account for changes in the average refractivity $n$ from the $\lambda_{\max }=n p$ relation (as proposed in [14]) is also of no use, since the values of refractivity index $n$ for trans- and cis-forms of azoxy nematics differ by less than $1 \%$ [7]. 


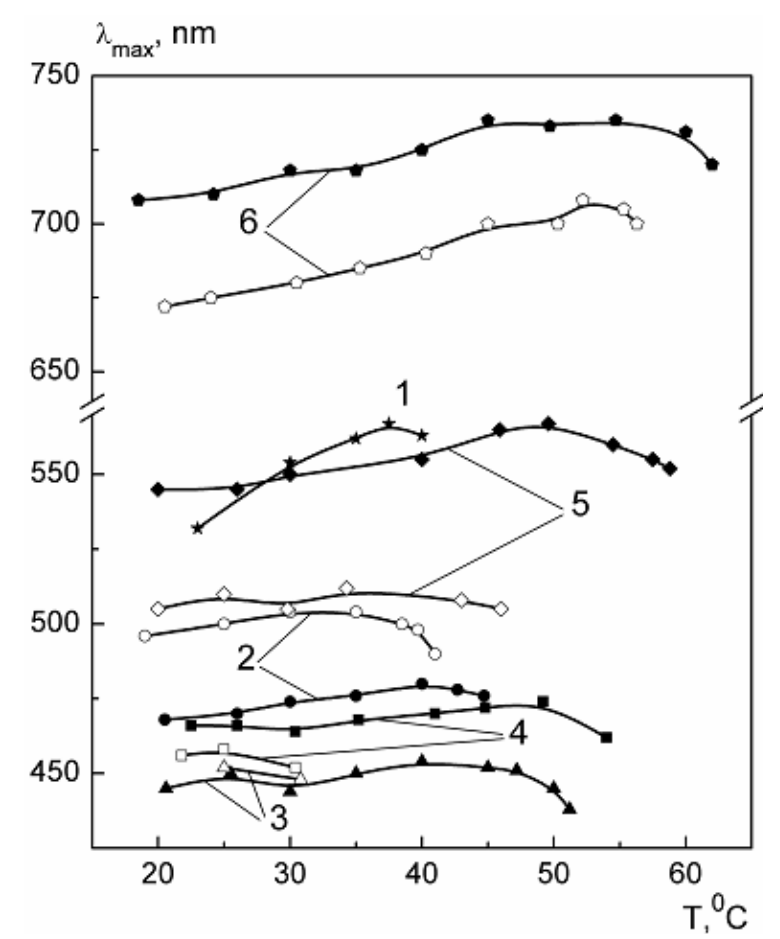

Fig. 1. Selective reflection maximum $\lambda_{\max }(T)$ as a function of the temperature for nematic-cholesteric systems M23 + azoxy nematic ZhK-440 before (black symbols) and after (white symbols) UV irradiation. Content of ZhK-440: $1-0 \%$ (cholesteric mixture M23), 2-10\%, 3-25\%, 4-35\%, 5-50\%, 6-65\%

Summing up, one can say that the most important characteristic feature of cholesteric systems with photosensitive azo- and azoxy nematics is an anomalous decrease in the helical pitch (i.e., additional helical twisting) under UV irradiation as a result of the formation of cis-isomers. This behavior has no clear explanation within the available theories of cholesteric mesophase.

In our work, we studied the helical pitch in such systems as a function of the temperature and the concentration of the photoactive azoxy nematic and its changes under UV irradiation. For the theoretical description of these systems, we used our approach previously developed in $[12,13]$ for cholesteric systems with nonmesogenic dopants.

\section{Materials and Methods}

Our basic cholesteric liquid crystal (CLC) system comprised a cholesteric mixture M23 (18\% cholesteryl chloride $+82 \%$ cholesteryl oleyl carbonate) and a photoactive azoxy nematic ZhK-440 (NIOPIK, Russia). A necessary requirement was the non-overlapping of the electronic absorption and selective reflection bands. Selec- tive reflection spectra of a CLC planar texture were measured using a Hitachi 330 spectrophotometer equipped with a thermostabilized cell. The concentration of the nematic component was varied from 0 to $65 \%$, which ensured the selective reflection peaks in the visible range.

UV irradiation was carried out using a DRT-240 Hg lamp emitter in a geometry with the known distribution of spectral illuminance [15]. A typical UV radiation dose was $1.9 \mathrm{~J} / \mathrm{cm}^{2}$, which, according to [9], resulted in a photostationary state with about $50 \%$ of azoxy molecules in cis-form.

\section{Results and Discussion}

The temperature dependences of the selective reflection maximum $\lambda_{\max }$ were obtained before and after irradiation for nematic-cholesteric mixtures (M23+ZhK-440) with various contents of the photoactive nematic component. The typical results are presented in Fig. 1. The initial cholesteric matrix M23 is characterized by a small positive $d \lambda_{\max } / d T(2.8 \mathrm{~nm} / \mathrm{K})$; upon the addition of ZhK-440, this parameter changes non-monotonously. UV irradiation results in changes both in $\lambda_{\max }$ and the slope of its temperature dependence. Assuming that a variation of $n$ (both with temperature and upon irradiation) is negligible, we used the $\lambda_{\max }=n p$ relation, by taking $n=1.5$, which is close to the more exact values given in [7]. For the theory of helical twisting, the value that is of physical meaning is the inverse pitch $p^{-1}$, also called "helical twisting"; so, it is this value that we use in our discussion.

Let us consider the changes in the helical pitch caused by the trans-cis isomerization of ZhK-440 under irradiation. At low concentrations of the nematic, the formation of $c i s$-isomers leads to a decrease in the helical twisting, i.e., higher $\lambda_{\max }$. This correlates with the temperature behavior of the initial matrix $(d p / d T>0)$. When the nematic concentration is further increased (above the inversion point at $\sim 31 \%$ of $\mathrm{ZhK}-440$ ), the helical twisting is increased under irradiation, i.e., $\lambda_{\max }$ decreases. This contradicts the character of $d p / d T$.

The formation of a cis-isomer with low anisometry under UV irradiation can be considered as the introduction of a non-mesogenic dopant (NMD) into the system. Then we can apply the approach previously used in $[12$, 13] for the description of the effects of NMD on the helical twisting in cholesterics. 
The inverse pitch variation $\Delta p^{-1}$ due to the introduction of NMD is described as

$\Delta p^{-1}=\left(\gamma T \frac{\partial p_{0}^{-1}}{\partial T}-p_{0}^{-1}+k_{p}\right) \omega-$

$-\left(\gamma T \frac{\partial p_{0}^{-1}}{\partial T}+2 k_{p}\right) \frac{\omega^{2}}{2}$

where $T$ is the temperature, $\omega$ is the mass fraction of NMD in the cholesteric system, $p_{0}$ is the helical pitch of the initial cholesteric matrix, $k_{p}$ is a coefficient describing the extra helical twisting due to the orientation of the NMD molecule by the steroid ring of cholesterol derivatives, and $\gamma$ is a coefficient of NMD non-mesogeneity: it is equal to zero for mesogenic substances and equal to 1 for NMD with zero anisometry.

If, in the first approximation, we neglect the effects of the nematogenic trans-component depletion on the helical pitch, we can apply (1) to our case, modifying it in the following manner:

$$
\begin{aligned}
& \Delta p^{-1}=\omega_{c i s}\left[\gamma T \frac{\partial p_{\mathrm{bi}}^{-1}}{\partial T}\left(1-\frac{\omega_{c i s}}{2}\right)-p_{\mathrm{bi}}^{-1}+\right. \\
& \left.+p_{\mathrm{bi}} k_{c i s}\left(1-\omega_{c i s}\right) \omega_{c i s}\right] .
\end{aligned}
$$

Here, $\omega_{\text {cis }}$ is the mass fraction of the cis-isomer formed, $p_{\mathrm{bi}}$ is the helical pitch of the mixture before irradiation, and $k_{c i s}$ is a coefficient characterizing the effective helical twisting power of the cis-isomer formed in the system.

One can say that the phenomenological parameter $k_{p}$ from (1), characterizing a contribution from the interaction of molecules of the nematic and cholesteric components, is formally presented in the form $k_{p}=p_{\mathrm{bi}}^{-1} k_{c i s} \omega_{\text {cis }}$.

Calculated values of the inverse pitch variation $\Delta p^{-1}$ under UV radiation are shown in Fig. 2 together with experimental data. In Eq. (2), we took $\gamma=1$, since the cis-isomer formed is of practically zero anisometry. Since all measurements were carried out for a photostationary state, the value of $\omega_{\text {cis }}$ was taken as one-half of the mass fraction of ZhK-440 before irradiation, i.e., $\omega_{\text {cis }}=\omega / 2$ [9]. By varying the phenomenological parameter $k_{c i s}$, we determined the value $k_{\text {cis }}=8.15$ that ensured the best fit of experimental and calculated data.

The first term in the square brackets in (2) describes a decrease in the helical twisting of the system (with $\left.d p^{-1} / d T<0\right)$ under UV irradiation due to the lowering of the orientational order as a result of the formation of the non-anisometric cis-isomer. The second term

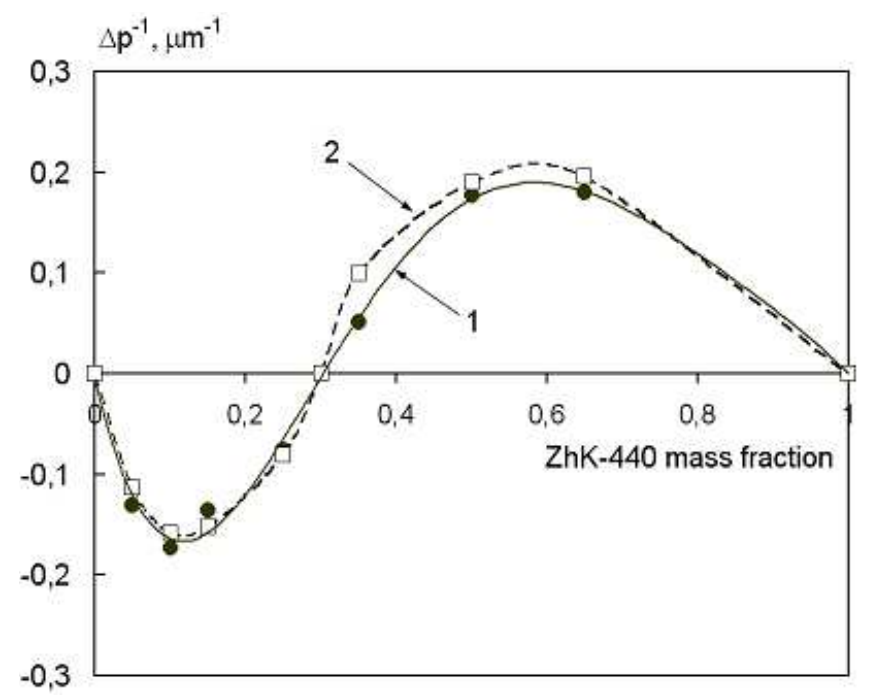

Fig. 2. Changes in the helical twisting induced by UV irradiation in the nematic-cholesteric system M23 + ZhK-440: 1 - experimental data obtained; 2 - values calculated according to Eq. (2)

describes a decrease in $p^{-1}$ caused by the lowering of the concentration of the initial nematic-cholesteric mixture (with pitch $p_{\mathrm{bi}}$ ) because of the appearance of a new component, the formally non-chiral cis-isomer. The third term describes the anomalous increase in the helical twisting with increasing $\omega_{\text {cis }}$. Thus, the formed non-mesogenic non-chiral cis-isomer acquires its effective twisting power (characterized by the parameter $k_{c i s}$ ) in the CLC chiral field. The sense of this twisting power, i.e., the predominance of the "conditionally left-handed" or "conditionally right-handed" form (orientation) of the cis-isomer molecule, is determined by the sign of the cholesteric helix that has been already present in the system [16]. A similar phenomenon was described in [17], where the enhancement of the helical twisting of a chiral nematic phase was observed under the introduction of non-chiral banana-shaped molecules. A more detailed analysis of the mechanism of such extra contribution to the helical twisting can be given using notions of "deracemization" of molecules of such type [18], developed within the concept of pseudo-scalar liquid crystals [19]. It is worth to note that the helical pitch change under UV radiation depends on two main factors: the value of $d p / d T$ of the cholesteric matrix before irradiation and the concentration of the formed cis-isomer $\omega_{\text {cis }}$. These parameters determine the presence of two extrema on the "UV-induced helical pitch change vs. the concentration of azoxy nematic" curve, as well as the inversion point of the $\Delta p^{-1} \operatorname{sign}$. At the same time, the value of 
$\gamma$ does not essentially affect the character of $\Delta p^{-1}(\omega)$ dependence.

1. I.P. Ilchishin, E.A. Tikhonov, V.G. Tishchenko, and M.T. Shpak, Pis'ma Zh. Eksp. Teor. Fiz. 32, 27 (1980).

2. G. Chilaya, A. Chanishvili, G. Petriashvili, R. Barberi, M.P. de Santo, and M.A. Matranga, Mater. Sci. and Appl. 2, 116 (2011).

3. I. Ilchishin, L. Lysetskiy, T. Mykytyuk, M. Serbina, and G. Chilaya, Mol. Cryst. Liq. Cryst. 542, 221 (2011).

4. I. Ilchishin, O. Yaroshchuk, S. Gryshchenko, and E. Shaydiuk, Proc. SPIE 5507, 229 (2004).

5. G.S. Chilaya, Crystal. Rep. 51, S108 (2006).

6. Y. Huang, Y. Zhou, Ch. Doyle, and S. Wu, Optics Express 14, 1236 (2006).

7. B. Kang, H. Choi, M.-Y. Jeong, and J.W. Wu, J. Opt. Soc. Am. B 27, 204 (2010).

8. I.P. Ilchishin, L.M. Lysetskiy, T.V. Mykytyuk, and M.I. Serbina, Ukr. J. Phys. 56, 333 (2011).

9. D. Aronzon, E.P. Levy, P.J. Collings, A. Chanishvili, G. Chilaya, and G. Petriashvili, Liq. Cryst. 34, 707 (2007).

10. A. Chanishvili, G. Chilaya, and G. Petriashvili, Mol. Cryst. Liq. Cryst. 434, 25 (2005).

11. G. Chilaya, A. Chanishvili, G. Petriashvili, R. Barberi, R. Bartolino, M.P. de Santo, M.A. Matranga, and P.J. Collings, Mol. Cryst. Liq. Cryst. 453, 123 (2006).

12. G.S. Chilaya and L.N. Lisetski, Mol. Cryst. Liq. Cryst. 140, 243 (1986).

13. L.N. Lisetski and T.P. Antonyan, Zh. Fiz. Khim 54, 1169 (1980).

14. V.A. Hrozhyk, S.V. Serak, N.V. Tabiryan, and T.J. Bunning, Adv. Funct. Mater. 17, 1735 (2007).

15. L.N. Lisetski, V.D. Panikarskaya, N.A. Kasian, L.V. Grishchenko, and I.P. Terenetskaya, Proc. SPIE 6023, $6023 \mathrm{OF}$ (2005).
16. M.I. Serbina, L.N. Lisetski, I.A. Gvozdovskyy, A.V. Kovalchuk, and G.S. Chilaya, Funct. Mater. 17, 449 (2010).

17. J. Thisayukta, H. Niwano, H. Takezoe, and J. Watanabe, J. Am. Chem. Soc. 124, 3354 (2002).

18. A.A. Gerasimov and S.V. Shiyanovskiy, Ukr. Fiz. Zh. 34, 1527 (1989).

19. Ya.B. Zeldovich, Zh. Eksp. Teor. Fiz. 67, 2357 (1974).

Received 26.09.11

ЕФЕКТИ УФ-ВИПРОМІНЮВАННЯ НА СПІРАЛЬНЕ ЗАКРУЧУВАННЯ У ХОЛЕСТЕРИЧНИХ СИСТЕМАХ, ЩО МІСТЯТЬ ФОТОЧУТЛИВІ АЗОКСИ-НЕМАТИКИ

М.І. Сербіна, Н.О. Касян, Л.М. Лисецъкиц

Р е $з$ ю м е

Для холестеричних рідкокристалічних систем, що містять фоточутливий нематик ЖK-440 та суміш похідних холестерину, досліджено зміни спірального закручування, викликані УФопроміненням. Показано, що УФ-індукований зсув максимуму селективного відбиття $\lambda_{\max }$ залежить від концентрації нематичного компонента. Для малих концентрацій ЖK-440, $\lambda_{\max }$ зростає, що корелює з відповідними температурно-індукованими змінами. Для більших концентрацій азокси-нематика $\lambda_{\max }$ знижується незалежно від температурної поведінки системи. Для пояснення експериментальних даних запропоновано теоретичний опис, який грунтується на розвитку молекулярних моделей спірального закручування. Отримано добре узгодження між розрахованими та виміряними значеннями УФіндукованого зсуву залежно від концентрації азокси-нематика, з двома екстремумами та точкою інверсії. Додаткове закручування виникає внаслідок орієнтації в холестеричній мезофазі коротких осей иис-ізомерів, що утворюються в результаті опромінення. 